\title{
Research Approaches to Terrorism: A Way Forward for New Zealand
}

Author/s: Eamonn Barnett and Nick Nelson

To cite this article: Barnett, E. \& Nelson, N. R. (2019). Research Approaches to Terrorism:

A Way Forward for New Zealand. National Security Journal, 1(1), 49-59.

doi:10.36878/nsj201901.49

To link to this article: https://doi.org/10.36878/nsj201901.49

View CrossRef data: https://search.crossref.org/?q=10.36878\%2FNSJ201901.49\# 


\title{
RESEARCH APPROACHES TO TERRORISM: A WAY FORWARD FOR NEW ZEALAND
}

\author{
Eamonn Barnett \& Nick Nelson ${ }^{1}$
}

\begin{abstract}
The study of contemporary terrorism is a complex issue that has been largely neglected as an academic pursuit in New Zealand. This, however, is likely to change following the tragic events in Christchurch on 15 March 2019. But how is this new research best undertaken? This article compares two key approaches to researching terrorism: the traditional, or orthodox, approach; and the critical terrorism studies approach. While each approach has its strengths and weaknesses, this article posits that more productive interaction between government agencies and academics will allow both approaches to be pursued which, in turn, offers the opportunity to more effectively address the threat that terrorism poses to $\mathrm{New}$ Zealand in both the short and the long term.
\end{abstract}

Keywords: New Zealand, Terrorism, Research, Traditional Terrorism Studies, Orthodox Terrorism Studies, Critical Terrorism Studies

The contemporary study of terrorism as a distinct subject began in the late 1960s and the field quickly grew and established itself. From the early 1970s a group of recognised 'terrorism experts' emerged; new research centres were established; and a body of literature began to be published, including in newly established specialist terrorism journals. ${ }^{1}$

What was gradually increasing interest exploded into the mainstream following Al-Qaeda's attacks on 11 September 2001. Following the attacks the subject of terrorism received a considerable increase in funding and resourcing, which naturally led to a significant increase in research and literature on the topic. ${ }^{2}$ Much of this research, largely as a consequence of its origins, was driven by state counter-terrorism priorities and, as such, it adopted a problem solving approach to produce knowledge for policy purposes $^{3}$. This approach has become known as the traditional, or orthodox, approach

1 Eamonn Barnett is a postgraduate student at the Centre for Defence and Security Studies at Massey University; Nick Nelson is a Senior Lecturer at the Centre for Defence and Security Studies at Massey University; contact N.R.Nelson@massey.ac.nz. 
to studying terrorism and tends to shape important issues of national security by producing knowledge within particular contexts and existing power relationships.

A second approach to studying terrorism, critical terrorism studies (CTS), has emerged over the last decade and is beginning to have a considerable impact on how terrorism is researched. While CTS is made up of a range of diverse perspectives, fundamentally it sees terrorism as a social fact as it relies on a series of subjective judgements about the various aspects of the action, rather than attempting to identify an objective truth. In this sense, CTS posits that knowledge about terrorism is never neutral but always serves someone's interests. CTS, thus, allows us to approach the study of terrorism using alternative frameworks and asking new kinds of questions. ${ }^{4}$ As a consequence, CTS differs from traditional studies of terrorism in a number of philosophical and practical ways.

Despite the global explosion in terrorism research post 2001, there remains a dearth of literature on the topic in New Zealand. However, the tragic events in Christchurch on 15 March 2019, which saw 51 members of New Zealand's Muslim communities killed and 49 others injured in an attack by a white supremacist, will likely change this and the authors expect to see a significant increase in the number of publications discussing terrorism in New Zealand.

This increase in research is essential to allow us to make sense of not only what occurred on 15 March 2019, but also to understand what may be occurring with regards to terrorism, violent extremism, and radicalisation more broadly in New Zealand, as well as globally, and what the likely impacts of this are. Gaining this understanding will be critical to improving our future counter-terror measures and reducing the risk of this kind of event recurring.

But how is this research best conducted? The aim of this article is to compare and contrast two key approaches to researching terrorism: the traditional, or orthodox, approach; and the critical terrorism studies (CTS) approach. It will explore the philosophical and methodological underpinnings of each approach as well as their strengths and weaknesses, and discuss the political, practical, and academic implications of each approach. The article will conclude with some thoughts on a possible way forward for researching terrorism in New Zealand.

\section{Orthodox Terrorism Studies}

The origins of the orthodox approach to studying terrorism can be found in the 1960s, during the height of the Cold War and at a time when Western states and their allies were battling a range of revolutionary insurgencies across much of the globe. This orthodox approach emerged in the context of state based attempts to defeat the threats that these insurgencies posed. As a consequence of these origins, Jackson ${ }^{5}$ has identified four key characteristics of orthodox terrorism studies. Firstly, it has focussed almost 
exclusively on non-state terrorism, i.e. the use of terrorism by non-state individuals or groups. Secondly, it has focussed predominantly on groups that pose a threat to Western society. Thirdly, it adopts a problem-solving approach that focusses on providing solutions for state counter-terrorism policy. Fourthly, it studies terrorism as a stand-alone phenomenon rather than in the context of a broader range of contextual factors. As a consequence of these characteristics, orthodox terrorism studies approach the study of terrorism in a particular way at the ontological, epistemological, and methodological levels. This in turn has substantial practical, political, and academic implications.

Ontology deals with what exists, the nature of reality and what is out there to know. The majority of orthodox terrorism scholars view reality as fixed and measurable, with the object or social phenomenon of research remaining independent. ${ }^{6}$ This perspective stems from the natural sciences and mainstream social sciences, and is essentially an objectivist or problem-solving approach that largely disregards any contextual application such as time, place, or socio-political context. ${ }^{7} \mathrm{Cox}^{8}$ outlines the orthodox problem-solving approach as taking the prevailing social and power relationships as they are and then making them work by targeting and dealing with specific problems or issues. Blakeley, ${ }^{9}$ arguing a similar viewpoint, describes this approach as accepting, rather than challenging, existing institutions and social infrastructure, and argues that orthodox scholars consider the problem of terrorism within these existing conditions. In this sense, orthodox terrorism studies are intimately connected with the existing structures of power in society and research is aimed at finding solutions that maintain these.

At the epistemological level, the focus is on the nature of knowledge and how something can be known. An objectivist approach within orthodox terrorism studies naturally leads to its epistemology being dominated by positivism. ${ }^{10}$ Positivism views the study of social problems as identical to the study of scientific questions - knowledge is neutral, independent from the researcher, and the 'truth' is out there simply waiting to be discovered by a completely neutral researcher. ${ }^{11}$ Further, positivism highlights the importance of the existing social and power structures and looks to protect these from the problems of terrorism.

Specific methodologies and methods have emerged as a result of the orthodox approach's ontological and epistemological perspectives. Positivism lends itself to a quantitative approach with a heavy reliance on empirical evidence and observable, measurable facts. As such, orthodox methodologies tend to focus on large scale data collection, experimental research and statistical analysis. ${ }^{12}$ The methods that emerge often include: document analysis (particularly secondary source documents), measurement, questionnaires, and statistical analysis of large-N data sets. In a 1998 study Schmid and Jongman ${ }^{13}$ questioned fifty prominent terrorism researchers about their methods and where they obtained their information and data from. The results showed that the majority relied heavily on examination of secondary source documents. In 2001, Silke, ${ }^{14}$ building on the earlier research of Schmid and Jongman, determined that there was 
still a limited range of methodological diversity and a heavy reliance on these particular methods within the field. These two reviews are substantial contributions to the literature on terrorism research, and accurately represent the methodological trends at the time they were conducted.

The justification for these methodological approaches stems from orthodox scholars viewing terrorism as a phenomenon that can be studied objectively using the traditional methods of the social sciences and, indeed, the natural sciences. ${ }^{15}$ On a practical level for orthodox scholars it is much easier to conduct secondary (rather than primary) source research. This is due to the sensitivity and clandestine nature of the agencies involved, and the difficulties in obtaining primary data, including obtaining access to the relevant actors and the personal risk that can come with this. ${ }^{16}$ Schuurman and Ei$\mathrm{jkman}{ }^{17}$ argue that accessing primary data is the "achilles' heel" of orthodox terrorism studies, while Silke ${ }^{18}$ explains that secondary data analysis involves much less effort and expense. These methodological considerations, the methods used and justifications result in a number of political, practical and academic consequences. ${ }^{19}$

The most significant of these implications is that as orthodox researchers tend to take an objectivist viewpoint, the majority of their research accepts the status quo and focuses on terrorism that poses a threat to the state while minimising or ignoring the arguably larger problem of state terrorism and terrorism that poses less of a threat to the status quo. This approach strengthens the state's position of power and reinforces the divide between the 'good' state and the 'bad' terrorist. Herman and O'Sullivan ${ }^{20}$ took note of this phenomenon and spoke of these scholars as being part of a wider "terrorism industry". They argued that some 'experts' were a cover for state interests and only sought to reinforce the state's position of power. Similarly, Reid ${ }^{21}$ spoke of "invisible colleges" of orthodox researchers that solely focused on terror from below. Many other authors have identified this association, primarily out of concern for potential bias and a lack of academic neutrality ${ }^{22}$ and have questioned the research community's "intricate and multifaceted links with the structures and agents of state power" 23 along with the consequent influence this has had on shaping their research. The implications of failing to question the existing political and social structures are far-reaching. Political elites can use orthodox academic discourse to promote specific political ventures like the development of extensive surveillance systems; the normalisation of intensive security protocols; the expansion of powers and jurisdiction of the state; the control of social dissent; and even the restriction of human rights. ${ }^{24}$ Silke ${ }^{25}$ also highlights the fact that orthodox research is often driven by policy concerns which limit it to fulfilling government agendas. This is an issue as government agendas are often focused on short term results and can divert research attention and resources down strategically unproductive avenues.

Despite these implications there are certain strengths to approaching terrorism studies from an orthodox and objectivist perspective. While challenging the orthodox position, $\mathrm{Cox}^{26}$ fairly recognised an ability of the problem-solving approach to confront problems 
through simplifying them and fixing limitations or parameters to the issue. He argues that by doing this it is possible to reach statements and regularities that can be useful when considered within the context of the limitations. Further to this, Gunning, ${ }^{27}$ again endorsing a more critical approach, argues that because the problem-solving approach does not constantly question itself and operates within fixed constraints, it can "offer very practical advice where 'critical' perspectives often struggle to go beyond critique". Where it can offer practical advice, the approach can also offer practical benefits. One such benefit is that because orthodox studies relies so heavily on the analysis of secondary data ${ }^{28}$ it expends significantly less effort and resources to obtain primary data, a considerable advantage within a field where it can be notoriously difficult to obtain raw information. ${ }^{29}$

Notwithstanding these strengths, there are a number of criticisms and weaknesses concerning the orthodox approach which have routinely been put forward by CTS. The first of these is that there is a distinct lack of conceptual self-awareness within the field. ${ }^{30}$ Dixit and Stump ${ }^{31}$ analysed forty syllabi in United States' universities and found that ontological, epistemological and methodological debate is minimised, which limits academic rigour and development. Further to this, Silke ${ }^{32}$ showed that during the $1990 \mathrm{~s}$ only $1.6 \%$ of papers within the field could be regarded as primarily conceptual papers, with the focus on the definitional debate rather than any philosophical reflection. A second common criticism is that the majority, over 90 percent, of published work has been done by single researchers, often with no academic background in the field. ${ }^{33}$ This is a cause for concern as it means orthodox research is being conducted with limited resources and by those who may not fully appreciate previous research on the topic. A third weakness is the approach's heavy reliance on secondary sources and an overuse of literature reviews. Many authors have criticised this fact ${ }^{34}$ with Schmid and Jongman ${ }^{35}$ showing that only three out of fifty researchers claim to have generated their own data, and Silke $e^{36}$ arguing that secondary sources still dominate up to $80 \%$ of research. The issue with this is that researchers are not producing original data and can get drawn into a continually reinforcing feedback loop. ${ }^{37}$ Finally, many authors have raised concerns regarding the close relationship between orthodox researchers and the state, and an over-reliance on the problem-solving theory. ${ }^{38}$ They have convincingly argued that close ties between policy-makers and the orthodox academic community have led to event and policy driven research, and at times even biased publications that seek to strengthen the state's position of power.

\section{Critical Terrorism Studies}

CTS grew out of dissatisfaction with the state of terrorism research and the orthodox approach, and is firmly rooted in critical theory. Although CTS is a broad and evolving field made up of many diverse perspectives, Jackson ${ }^{39}$ notes that CTS approaches share a number of key concerns and commitments. First, they are sceptical of accept- 
ed knowledge and as part of the research process challenge that status-quo. Second, they emphasise the importance of the collection and analysis of primary source data as opposed to secondary source. Third, they are acutely aware that the production of knowledge is never a neutral process but is intimately connected with structures of power and they take steps to address this. Finally, they tend to prioritise human and societal security and will challenge the status quo to improve the lives of individuals and communities. As a consequence of these characteristics, CTS approaches the study of terrorism in a particular way at the ontological, epistemological, and methodological levels. This in turn has significant practical, political, and academic implications.

There is a substantial amount of research dedicated to the ontological and epistemological positions of CTS. While not claiming to offer any unified approach to the study of terrorism, it prefers to be thought of as a field that has adopted a generally critical approach. ${ }^{40}$ In doing this, CTS essentially adopts the ontological view of constructionism, whereby objects do not exist autonomously and the object and subject shape and interact with each other in an ongoing dynamic. ${ }^{41}$ In this sense, CTS sees terrorism as fundamentally a social fact that relies on a series of social, cultural, legal and political processes of interpretation, categorisation, and labelling. ${ }^{42}$ Further, CTS rejects the notion that it is possible to generalise about terrorism from one context to another and posits that to understand terrorism it must be contextualised in the environment in which it exists.

This leads to an interpretivist epistemological position where CTS scholars approach terrorism as a social construct rather than treating it as an independent phenomenon. ${ }^{43}$ In creating knowledge about the topic they take into account a range of historical and social contextual factors including, importantly, those about the researchers themselves - the social position, the institutional context and the methods employed. Furthermore, CTS scholars are unconvinced that completely objective knowledge about terrorism can be understood, and that knowledge must be obtained and analysed through the social context that it emerged from. ${ }^{44}$ Cox explains critical theory as standing apart from the prevailing social constructs and power structures, calling them into question rather than taking them for granted. ${ }^{45}$

These ontological and epistemological positions at the heart of CTS have a number of implications for both the methodology and methods in researching terrorism. Key of these is that CTS proponents endorse methodological and disciplinary plurality in their research, which is to say using not just different methodologies and methods, but also insights and perspectives from different disciplines, approaches and schools of thought. ${ }^{46}$ Given the focus on obtaining primary data, rather than secondary, and obtaining it in a manner that accounts for terrorism's social, political and cultural context, the methodology and methods typically used by CTS researchers tend to deal with much smaller sample sizes and are much more contextual in nature. The primary methodologies and methods used by CTS scholars include ethnography, critical discourse 
analysis ${ }^{47}$ case studies, process tracing ${ }^{48}$ interviews, ${ }^{49}$ and observation. While analytic approaches used by CTS scholars acknowledge the dominant social scientific methods of rationalism and empiricism, they argue that interpretive and reflectivist approaches are equally valuable to answer questions which are not possible to understand in terms of lineal notions of cause and effect.

As a consequence of its ontological, epistemological, and methodological approach, Jackson $^{50}$ has noted that CTS brings with it a range of practical, political and academic implications that need to be understood. Importantly, CTS aims to rebalance orthodox studies by moving the focus from a state-centric approach to security, to one focussed on the security and well-being of individuals and communities. This does not mean that CTS scholars are anti-state, far from it. Rather it means that in identifying solutions to address the threat posed by the phenomenon of terrorism, an improvement in human security and well-being is seen as paramount. In line with this, while CTS scholars are committed to influencing public policy, they differ in their approach to this from orthodox scholars in that they engage equally with both policy-makers (the state) and policy takers (groups and wider society who are impacted by terrorism and the counter-terrorism policies implemented) to ensure the voices of all those impacted are taken into consideration.

There are a number of strengths that have been a driving force behind the establishment and expansion of CTS. Key of these is that CTS has significantly broadened and deepened the discussion and self-reflection within the field of terrorism studies. In terms of broadening, it includes subjects that are often neglected in traditional studies such as the broader social and political contexts within which terrorism emerges, while deepening involves the uncovering of terrorism's philosophical and ideological underpinnings. This deepening and widening of thought is crucial as it has provoked important questions about the researcher-subject relationship, the production of knowledge, and the nexus between the academic community and the state. With regard to this latter point, the critical approach seeks to question the status quo and existing social and power structures rather than just accepting them. ${ }^{51}{ }^{52}$ In this sense, CTS has been instrumental in shining the spotlight back on the state as well as on the various threats that do not impact the status quo and, thus, re-balancing the existing literature's asymmetric focus. CTS has also had a substantial impact on how research is conducted within the field. Jackson ${ }^{53}$ explains that after criticising the over-reliance on secondary sources by orthodox scholars, CTS has sought to increase the amount of primary data gathered and has attempted to take into account the social and historical context of that data. This approach has led to increased study on typically under-emphasised topics, including gender, culture, and counter-terrorism practises. ${ }^{54}$

The emergence of CTS has also brought a number of criticisms and orthodox scholars have countered the approach with various arguments which typically centre on three issues. The first of these is that CTS overstates the novelty of its case. Orthodox scholars 
have criticised CTS for failing to acknowledge that many of the weaknesses and inconsistencies of the orthodox approach, such as definitional issues, the minimisation of state terrorism, ahistorical research, and a lack of conceptual analysis have already been identified and researched extensively by scholars within orthodox terrorism studies. ${ }^{55}$ The second argument is that the CTS approach overstates its significance and claims. Orthodox scholars, and many practitioners, argue that the CTS approach is good at criticising the orthodox approach but without offering anything in the way of useful practical alternatives on how to protect a nation's citizens from the threats posed by terrorism. They note that instances of transformation in dealing with terrorism by CTS scholars are scant and that practical advice tends to elude the approach. ${ }^{56}$ The third, and probably most damning, criticism of CTS is the 'straw person' argument - that CTS has a tendency to make a 'straw person' out of more than forty years of knowledge gained from the traditional approach. While orthodox terrorism studies have largely overlooked discussion on prevailing power structures, such criticisms as orthodox scholars being "solely interested in telling comforting lies to those in power" ${ }^{37}$ make a mockery of the valuable research that has been undertaken by traditional scholars.

\section{Conclusion}

As the above discussion of the orthodox and CTS approaches to studying terrorism highlights, studying terrorism is a complex undertaking. The orthodox viewpoint is objectivist in nature and accepts the existing social and power structures. Orthodox researchers typically approach terrorism using problem-solving theory and often fail to account for contextual and historical dynamics. While this approach has some considerable strengths and provides policy-makers with tangible solutions to address, in part, the threat posed by terrorism, the approach has been criticised by CTS for its lack of conceptual self-reflection, heavy reliance on secondary sources and close relationship with the state which results in predominantly 'hard power' solutions that solve shortterm problems but are less effective in the longer term.

CTS has been an important development in the field of terrorism studies and has brought the focus back to issues that have been overlooked or dismissed by orthodox scholars. It takes a differing ontological position emphasising that the object and subject do not exist independently and knowledge on the topic of terrorism is socially and politically constructed rather than objective. Its focus on the use of primary rather than secondary data; its broader engagement and consideration of cultural, historical and political factors; and its challenge to existing social and power structures provide a contrast to orthodox studies and results in an approach that, despite its weaknesses, can provide broader 'soft power' solutions that may be more effective in the longer term.

So what does all of this mean for the study of terrorism in New Zealand? While there remains a dearth of published academic literature on contemporary terrorism in New Zealand, there is no doubt that terrorism research is undertaken within New Zealand's 
government agencies. It is likely, however, that much, if not all, of this research is orthodox in nature: adopting a problem-solving approach, maintaining terrorism as a major public policy concern that limits itself to fulfilling government agendas, and producing knowledge that maintains existing power structures. While this has short-term benefits, it suffers from being insufficiently sensitive to the ways in which knowledge and power are connected. It also results in the development of a number of subtle gate-keeping processes that protect power by restricting access to data and policy-makers to very few 'insiders' who share the same, dominant perspective. This poses a longer term risk - denying the opportunity for terrorism to be explored through alternative frameworks that have the potential to broaden and deepen our understanding of the phenomenon. This, in turn, severely limits the opportunity to identify new innovations which may more effectively address the threat that terrorism poses in the longer term.

Perhaps there is an opportunity for New Zealand to take note of the significant benefits accrued by the more recent approach to terrorism research in France and the Netherlands where primary source information is readily shared between agencies and academics. To do this will require the political will and courage to seek productive interactions between the agencies and academia that allow both approaches to researching terrorism to be pursued. Doing this will provide the opportunity for trained researchers to utilise their methodological and disciplinary capabilities to develop useful and, potentially, counter-intuitive insights into how New Zealand might best address the threats posed by terrorism. Not doing this risks the stagnation of terrorist research in New Zealand as a consequence, to quote Marc Sageman ${ }^{58}$ of the fact that we have "a system of terrorism research where intelligence analysts know everything but understand nothing, while academics understand everything but know nothing". This will in no way help New Zealand and its fight against terrorism moving forward.

1 Richard Jackson and others, Terrorism: A Critical Introduction (New York: Palgrave Macmillan, 2011).

2 Andrew Silke, "Contemporary terrorism studies: Issues in research" in Critical Terrorism Studies: A New Research Agenda, eds. R. Jackson, M. Smyth, \& J. Gunning (New York: Routledge, 2009).

3 Jackson, Terrorism: A Critical Introduction.

4 Ibid.

5 Ibid.

6 L. Jarvis, "Critical terrorism studies after 9/11," in Routledge Handbook of Critical Terrorism Studies, ed. R. Jackson (New York: Routledge, 2016); S. Lindahl, A Critical Theory of Counterterrorism (New York: Routledge, 2018)

7 P. Bunyavejchewin, "The orthodox and critical approach towards terrorism: An overview". Southeast Current 8, (2011): 34-42. Available at http://www.apu.ac.jp/rcaps/uploads/fckeditor/publications/workingPapers/RCAPS_WP10-3.pdf

8 R. Cox, "Social forces, states and world order: Beyond international relations theory". Millennium: Journal of International Studies 10, no.2 (1981): 126-155.

9 R. Blakeley, "Bringing the state back into terrorism studies." European Political Science 6, no. 3 (2007): 228-235. 
10 J. Gunning, “A case for critical terrorism studies?" Government and Opposition 42, no. 3 (2007): 363-393.

11 Jackson, Terrorism: A Critical Introduction.

12 G. Goertz, \& J. Mahoney, "Concepts and measurement: Ontology and epistemology," Social Science Information 51, no.2 (2012): 205-216; R. Jackson 'Knowledge, power and politics in the study of political terrorism' in Critical Terrorism Studies: A New Research Agenda, eds. R. Jackson, M. Smyth, \& J. Gunning (New York: Routledge, 2009); A. Silke, 'The devil you know: Continuing problems with research on terrorism'. Terrorism and Political Violence 13, no. 4 (2001): 1-14.

13 A. Schmid \& A. Jongman, Political Terrorism: A New Guide to Actors, Authors, Concepts, Data Bases, Theories \& Literature (New York: Routledge, 1988).

14 Silke, The devil you know: Continuing problems with research on terrorism.

15 R. Jackson, M. Smyth, \& J Gunning, "Introduction: The case for critical terrorism studies," in Critical Terrorism Studies: A New Research Agenda, eds. R. Jackson, M. Smyth, \& J. Gunning (New York: Routledge, 2009).

16 J. Horgan, "The case for first hand research" in Research on Terrorism: Trends, Achievements and Failures, ed. A Silke (Oxon: Routledge, 2004); A. Silke. 'The road less travelled: Recent trends in terrorism research' in Research on Terrorism: Trends, Achievements and Failures, ed. A Silke (Oxon: Routledge, 2004).

17 B. Schuurman, \& Q. Eijkman, "Moving terrorism research forward: The crucial role of primary sources," International Centre for Counter-Terrorism Research Papers 4, no. 2 (2013): 1-11.

18 Silke, The devil you know: Continuing problems with research on terrorism.

19 Lindahl, A Critical Theory of Counterterrorism; J. Stump, "Methodology and the critical study of terrorism," in Routledge Handbook of Critical Terrorism Studies, ed. R. Jackson (New York: Routledge, 2016).

20 E.Herman, \& G. O'Sullivan, The Terrorism Industry: The Experts and Institutions that Shape our View of Terror (New York: Pantheon Books, 1989).

21 E. Reid, "Evolution of a body of knowledge: An analysis of terrorism research," Information Processing \& Management 33, no. 1 (1997): 91-106.

22 J. Franks, "Rethinking the roots of terrorism: Beyond orthodox terrorism theory - A critical research agenda," Global Society 23, no. 2 (2009): 153-176; M. Halkides, 'How not to study terrorism'. Peace Review 7, no. 3-4 (1995): 253-260; Jarvis, Critical terrorism studies after 9/11; Schmid \& Jongman, Political Terrorism: A New Guide to Actors, Authors, Concepts, Data Bases, Theories \& Literature.

23 S. Raphael, "In the service of power: Terrorism studies and US intervention in the global South," in Critical Terrorism Studies: A New Research Agenda, eds. R. Jackson, M. Smyth, \& J. Gunning (New York: Routledge, 2009, p. 49).

24 Jackson, Knowledge, power and politics in the study of political terrorism.

25 Silke, The devil you know: Continuing problems with research on terrorism.

26 Cox, Social forces, states and world order: Beyond international relations theory.

27 Gunning, A case for critical terrorism studies?

28 Horgan, "The case for first hand research; Schmid \& Jongman," Political Terrorism: A New Guide to Actors, Authors, Concepts, Data Bases, Theories \& Literature. Silke, The devil you know: Continuing problems with research on terrorism.

29 Silke, The devil you know: Continuing problems with research on terrorism.

30 C. Baker-Beall, 'Is critical terrorism studies a useful approach to the study of terrorism?' in Contemporary Debates on Terrorism, eds. R. Jackson, \& D. Pisoiu (Oxon: Routledge, 2018); R. Jackson, 'The core commitments of critical terrorism studies," European Political Science 6, no.3 (2007): 244-251.

31 P. Dixit, \& J. Stump, "A response to Jones and Smith: It's not as bad as it seems; Or five ways to move critical terrorism studies forward," Studies in Conflict \& Terrorism 34, no.6 (2011): 501-511.

32 Silke, The road less travelled: Recent trends in terrorism research.

33 B, Schuurman, "Research on terrorism, 2007-2016: A review of data, methods, and authorship," Terrorism and Political Violence (2018):1-16; Silke, The devil you know: Continuing problems with research on terrorism; Silke, Contemporary terrorism studies: Issues in research; L. Stampnitzky, "Disciplining an unruly field: Terrorism experts and theories of scientific/intellectual production," Qualitative Sociology 34, no. 1 (2011): 1-19. 
34 Gunning, A case for critical terrorism studies?; Halkides, How not to study terrorism; Horgan, The case for first hand research; Schuurman, \& Eijkman, Moving terrorism research forward: The crucial role of primary sources.

35 Schmid \& Jongman, Political Terrorism: A New Guide to Actors, Authors, Concepts, Data Bases, Theories \& Literature.

36 Silke, The devil you know: Continuing problems with research on terrorism.

37 A. Dolnik, "Introduction: The need for field research on terrorism," in Conducting Terrorism Field Research: A Guide, ed. A. Dolnik (Oxon: Routledge, 2013).

38 R. Blakeley \& S. Raphael, "Understanding Western state terrorism" in Routledge Handbook of Critical Terrorism Studies, ed. R. Jackson (New York: Routledge, 2016); Halkides, How not to study terrorism; Jackson, The core commitments of critical terrorism studies; M. Ranstorp, "Mapping terrorism studies after 9/11: An academic field of old problems and new prospects," in Critical Terrorism Studies: A New Research Agenda, eds. R. Jackson, M. Smyth, \& J. Gunning (New York: Routledge, 2009); Schmid \& Jongman, Political Terrorism: A New Guide to Actors, Authors, Concepts, Data Bases, Theories \& Literature.

39 Jackson, Terrorism: A Critical Introduction.

40 Baker-Beall, Is critical terrorism studies a useful approach to the study of terrorism?

41 Bunyavejchewin, The Orthodox and Critical Approach Towards Terrorism: An Overview.

42 J. Zulaika \& W. Douglass, Terror and Taboo: the Follies, Fables, and Faces of Terrorism (New York: Routledge, 1996).

43 Jackson, The core commitments of critical terrorism studies; Lindahl, A Critical Theory of Counterterrorism.

44 Baker-Beall, Is critical terrorism studies a useful approach to the study of terrorism?

45 Cox, Social forces, states and world order: Beyond international relations theory.

46 J. Stump, \& P. Dixit, Critical Terrorism Studies: An Introduction to Research Methods (Oxon: Routledge, 2013).

47 Lindahl, A Critical Theory of Counterterrorism; J. Stump, \& P. Dixit, 'Studying terrorism and practicing criticism' in Critical Methods in Terrorism Studies, eds. P. Dixit, \& J. Stump (Oxon: Routledge, 2016).

48 Stump, Methodology and the critical study of terrorism.

49 J. Post, E. Sprinzak, \& L. Denny, "The terrorists in their own words: Interviews with 35 incarcerated Middle Eastern terrorists," Terrorism and Political Violence 15, no. 1 (2003): 171-184.

50 Jackson, Terrorism: A Critical Introduction.

51 Cox, Social forces, states and world order: Beyond international relations theory.

52 Jarvis, Critical terrorism studies after 9/11.

53 Jackson, Terrorism: A Critical Introduction.

54 R. Jackson, "Introduction: A decade of critical terrorism studies," in Routledge Handbook of Critical Terrorism Studies, ed. R. Jackson (New York: Routledge, 2016).

55 J. Horgan, \& M. Boyle, "A case against "critical terrorism studies", Critical Studies on Terrorism 1, no. 1 (2008): 51-64; J. Lutz, "A critical view of critical terrorism studies," Perspectives on Terrorism 4, no. 6 (2010): 31-40.

56 R. Devetak, "Critical Theory," in Theories of International Relations, eds. S. Burchill, A. Linklater, R. Devetak, J. Donnelly, M. Paterson, C. Reus-Smit, \& J. True (New York: Palgrave Macmillan, 2005).

57 Horgan \& Boyle, A case against critical terrorism studies (p. 54).

58 M. Sageman, "The stagnation in terrorism research," Terrorism and Political Violence 26, no. 4 (2014):565-580. 